\title{
The Power of the Multitude: Answering Epistemic Challenges to Democracy
}

\author{
Samuel Bagg
}

NB: this is the "author-approved" version (AAV) of the manuscript

(i.e., the final draft after peer review and before publisher edits)

Journal: American Political Science Review 112 (4)

Accepted: 20 July 2018

Published online by Cambridge: 6 September 2018 (link; doi: 10.1017/S0003055418000527)

AAV available on academia.edu: 6 September 2018 (link)

AAV available on ssrn.com: 26 September 2018 (link)

\begin{abstract}
Recent years have witnessed growing controversy over the "wisdom of the multitude." As epistemic critics drawing on vast empirical evidence have cast doubt on the political competence of ordinary citizens, epistemic democrats have offered a defense of democracy grounded largely in analogies and formal results. So far, I argue, the critics have been more convincing. Nevertheless, democracy can be defended on instrumental grounds, and this essay demonstrates an alternative approach. Instead of implausibly upholding the epistemic reliability of average voters, I observe that competitive elections, universal suffrage, and discretionary state power disable certain potent mechanisms of elite entrenchment. By reserving particular forms of power for the multitude of ordinary citizens, they make democratic states more resistant to dangerous forms of capture than non-democratic alternatives. My approach thus offers a robust defense of electoral democracy, yet cautions against expecting too much from it - motivating a thicker conception of democracy, writ large.
\end{abstract}

Key Words: epistemic democracy, epistocracy, meritocracy, voter ignorance, realism

Acknowledgments: For valuable feedback and discussion on the themes of this essay, I am very grateful to Arash Abizadeh, Aaron Ancell, Pablo Beramendi, Kevin Elliot, Michael Gillespie, Kelly Gordon, Ruth Grant, Jeffrey Green, Ewan Kingston, Jack Knight, Elizabeth Landesberg, Catherine Lu, Victor Muñiz-Fraticelli, Wayne Norman, Will Roberts, Amit Ron, Christa Scholtz, Melissa Schwartzberg, Lucas Swaine, Daniel Weinstock, and Yves Winter, as well as Leigh Jenco and several anonymous reviewers at the APSR. 


\section{Power, not Wisdom: The Realist Case for Democracy}

Democracy faces increasingly pressing challenges on "epistemic" grounds (Bell 2015; Brennan 2016; Caplan 2007; Somin 2013). Though few dispute its superior track record in the $20^{\text {th }}$ century, even committed democrats worry about the political ignorance, short-sightedness, and irrationality of ordinary citizens (Achen and Bartels 2016; Green 2009). Given these worries, indeed, many political philosophers assume that a purely "instrumental" defense of democracy is unstable, concluding that the value of political equality must be conceived in "non-instrumental" or "intrinsic" terms (Griffin 2003; Kolodny 2014; Viehoff 2014). Such arguments are hardly decisive, however (Arneson 2004; Wall 2007), and in the face of rising enthusiasm for nondemocratic alternatives (Foa and Mounk 2016), others have wisely insisted on justifying democracy in instrumental terms. In particular, recent years have witnessed growing interest in epistemic accounts of democracy (Estlund 2008; Landemore 2012), which directly answer epistemic challenges by defending the "wisdom of the multitude" (Waldron 1995).

This epistemic approach to evaluating rival regimes has a venerable history, dating all the way back to Plato and Aristotle. Unfortunately, it is also deeply misleading. In focusing on who has the appropriate skills and knowledge to govern rather than the complex dynamics of political power, critics routinely overstate the attractiveness of non-democratic alternatives like meritocracy. Meanwhile, defenders of democracy often understate the challenges of voter ignorance, which prevents them from articulating a robust, realistic account of democracy's instrumental value. Developing a more compelling response to epistemic challenges requires that we turn our gaze from questions of wisdom to questions of power. This essay outlines such an approach.

On the one hand, evidence of serious epistemic deficits ought to chasten our expectations for electoral democracy-defined minimally as any system characterized by competitive elections, universal suffrage, and substantial discretionary state power. Nevertheless, each of these three 
components is indispensable. As I demonstrate in what follows, non-democratic institutional alternatives would grant incumbents and other elites too much latitude to entrench their own power, presenting unacceptable dangers of "state capture" without generating significant or systematic compensatory benefits. Though electoral democracy is hardly free of such pathologies, each of its three central components does enhance resistance to particularly dangerous forms of entrenchment and capture - even if ordinary people are as politically incompetent as critics claim. My approach thus provides a more robust defense of basic democratic institutions than is available on other instrumental approaches, without implying any kind of complacency about them. It yields an appropriately enthusiastic appraisal of electoral democracy-i.e., as a justly celebrated achievement that is nonetheless profoundly insufficient — while encouraging a thicker conception of democracy, writ large.

My account is not entirely unprecedented-indeed, it builds on recent efforts to establish realistic foundations for democratic theory (Green 2009, 2016; Knight and Johnson 2011; Medearis 2015; Przeworski 2010; Rahman 2016; Shapiro 2003, 2016), and responds more generally to growing interest in "realist" alternatives to overly moralized or idealized ways of doing political philosophy (Bagg 2016, 2017; Galston 2010; Mantena 2012; Williams 2005). Yet it is unique in engaging directly with both epistemic critiques and non-democratic alternatives. Moreover, it integrates a number of disparate insights within a comprehensive theoretical framework, oriented around a novel ideal of resisting state capture.

In short, I claim, the value of competitive elections, universal suffrage, and discretionary state power is not to bestow ultimate authority upon the demos as the wisest possible sovereign. Instead, the value of each of these crucial democratic institutions is best understood in terms of the power it denies to various elites, and which is thereby retained by various groups of ordinary citizens. 
The most promising paradigm for answering epistemic challenges to democracy, I conclude, will emphasize the power, not the wisdom, of the multitude.

\section{The Epistemic Frame: Evaluating the Wisdom of the Multitude}

\section{Epistemic Critiques of Democracy}

With fascism and communism as its most salient opponents, electoral democracy came to enjoy near-universal support in the $20^{\text {th }}$ century - at least among Western cultural elites. Even as scholars accumulated staggering evidence of the political ignorance of ordinary voters (Campbell et al. 1960; Zaller 1992), most nonetheless embraced Winston Churchill's view of democracy as the "worst form of government, except for all the others that have been tried."

Recently, however, some have begun to venture more full-throated criticisms. Jason Brennan argues, for instance, that if people have a right to competent government, we should not leave decisions in the hands of the "ignorant, irrational, misinformed nationalists" of typical electorates $(2016,23)$. He then outlines a number of potential alternatives to one-person-one-vote, including restricted suffrage and plural or weighted voting. Given democracy's serious and demonstrable flaws, he argues, we have a responsibility to give such alternatives a try. Daniel A. Bell (2015) raises similar concerns from a rather different perspective, defending a quasi-Confucian political meritocracy modeled on contemporary Singapore and China, which eliminates competitive elections altogether. Such proposals to allocate political power on the basis of knowledge or merit, rather than giving it freely to everyone, are sometimes called "epistocracies" (Estlund 2008).

Epistemic skepticism of popular rule has an unflattering history, and it is often dismissed as obsolete. Yet electoral democracy faces troubling practical challenges in the $21^{\text {st }}$ century (Dresden and Howard 2016), and serious normative worries have come from diverse intellectual quarters. Libertarians lament widespread ignorance about economic policy (Caplan 2007), for instance, and 
egalitarians suspect popular commitment to fundamental rights (Dworkin 1996). Environmentalists bemoan the impact of short-sighted democratic choices on natural systems (Humphrey 2007), while radicals doubt the ability of electoral democracies to overcome systemic pathologies such as bourgeois ideology, patriarchy, white supremacy, and settler colonialism (Coulthard 2014; Davis 2012; Gramsci 1971; Malcolm X 1964).

Democrats typically rely on one of two strategies for defending competitive elections with universal suffrage. First, many emphasize their intrinsic value, maintaining that everyone deserves a say over decisions that bind them. Others prefer to stress the instrumental benefits of democratic institutions, observing that modern democratic governments have most reliably promoted peace and prosperity (Sen 1999). Both of these common accounts, however, fail to adequately address recent epistemic critiques.

As Brennan and Bell readily admit, for one, highlighting the extent of voter ignorance will rarely sway those who take the intrinsic value of democracy as a foundational normative premise. Yet this premise is neither self-evident nor universally shared. ${ }^{1}$ If ceding a largely symbolic form of political equality like universal suffrage would really yield dramatic improvements in social, economic, and environmental outcomes, this tradeoff would understandably appeal to many observers around the world. This hardly constitutes a thorough rebuttal of arguments for democracy's intrinsic value, of course, but given that these arguments are both reasonably contestable in theory and widely disputed in practice, democrats would be unwise to ignore the domain of instrumental value altogether. ${ }^{2}$ In what follows, therefore, I set aside intrinsic concerns.

\footnotetext{
${ }^{1}$ Indeed, the percentage of people globally who believe democracy is "essential" has declined dramatically in recent years (Foa and Mounk 2016).

${ }^{2}$ For more comprehensive arguments against intrinsic accounts of democracy-whose intuitive plausibility often relies on implicit instrumental assumptions — see Arneson (1993, 2004), Wall (2007), and Brennan (2016).
} 
Similarly, epistemic critics happily acknowledge electoral democracy's relative instrumental success - especially in the $20^{\text {th }}$ century (Bell 2015, 7; Brennan 2016, 8, 195). Yet it hardly constitutes a guarantee of peace, prosperity, and liberal rights (Levitsky and Way 2010); much less a thorough "democratization" of social and economic life (Crouch 2004; Tilly 2007). Meanwhile, democracies have also done awful things_especially to noncitizens (Bell 2015, 4647). Isn't it possible, critics ask, that some alternative might perform even better?

Ultimately, I argue, the answer is no: no epistocratic political institutions offer reliable substantive advantages over electoral democracy, all things considered. Especially given pervasive findings of voter ignorance, however, epistemic critics are right to be dissatisfied with the reasoning offered by prevailing accounts. Despite an almost axiomatic faith in democracy, democratic theorists still lack a compelling instrumental explanation of why competitive elections and universal suffrage should not be abandoned in favor of alternative institutions that would maintain attractive features of liberal government while filtering out the ignorance, irrationality, and bigotry of ordinary citizens. ${ }^{3}$ As a result, existing instrumental accounts remain perpetually vulnerable to challenges from novel forms of non-democracy, like those proposed by Brennan and Bell, which are said to transcend the limitations of earlier forms.

Such challenges can be understood as versions of the perennial "benevolent dictator" objection-i.e., that if rule by an intelligent and well-intentioned monarch or aristocratic elite could achieve better results than rule by the people, instrumentalists should prefer it to democracy. ${ }^{4}$

\footnotetext{
${ }^{3}$ Defenders of instrumentalism have typically been more concerned with debunking intrinsic views than explaining democracy's real instrumental value (e.g., Arneson 2004; Wall 2007). Minimalist accounts articulated by political scientists like Przeworski $(1999,2010)$ and Achen and Bartels $(2016,316-19)$ offer more-and they inform my own (more comprehensive) account-yet they remain remarkably unpopular (if not entirely unknown) in political philosophy.

${ }^{4}$ In response, democrats since Mill have hypothesized that political participation has intrinsic benefits for people. Yet as Brennan (2016, 54-73) shows, empirical research on this subject is not encouraging. As Bell $(2015,168-78)$ emphasizes, moreover, local democratic participation is perfectly consistent with meritocracy "at the top."
} 
Many democrats are troubled by this objection, which has often spurred the development of intrinsic accounts of democracy's value (Beitz 1989, 98; Christiano 1996, 16-17, 56; Kolodny 2014, 202). If instrumentalism yields only a contingent, defeasible commitment to democratic institutions, they conclude, democrats had better rely on the intrinsic value of political equality and self-government. Meanwhile, many instrumentalists embrace the hypothetical prospect of attractive alternatives to democracy. Until recently, however, few have taken this prospect seriously.

We no longer have this luxury. Given the urgent practical and philosophical challenges facing electoral democracy, we cannot be content that it is less awful than the other systems we have tried. We must also explain to challengers like Brennan and Bell—and, more importantly, to reformers and revolutionaries around the world — why we should refrain from trying anything else.

\section{Epistemic Defenses of Democracy}

That is why the "epistemic" account of democracy gaining popularity among political philosophers appears so promising (Anderson 2007; Bohman 2006; Estlund 2008; Landemore 2012; Misak 2008; Ober 2008). Unlike many intrinsic accounts, epistemic views acknowledge that the quality of the outcomes produced by democratic procedures is central to their justification. Unlike their instrumentalist rivals, however, epistemic accounts promise a coherent explanation of why we should expect democratic procedures to produce better outcomes than non-democratic alternatives: only democratic procedures, they claim, can harness the collective wisdom of the people. As a whole, that is, the demos possesses greater wisdom than the wisest philosopher-king or council of experts, and so democracy — a system in which the demos is sovereign-will outperform even the most benevolent of monarchies or aristocracies. Compared to other instrumentalist approaches, then, epistemic accounts stake out a far more robust commitment to 
democratic procedures. The connection between democracy and superior outcomes is not just a historical accident, but a deep and abiding principle of social organization.

Content neutrality is key here. Most instrumentalist accounts emphasize the connection between democratic procedures and specific substantive outcomes-i.e., maintaining liberal rights or avoiding famine and war-which inevitably invites "benevolent dictator" objections. On epistemic accounts, by contrast, democracy is more like the scientific method: we can trust it to reach political truths, in the long run, without knowing those truths in advance (Gaus 2011). As Sean Ingham summarizes, epistemic democrats aim to show that "democratic institutions have a tendency to produce reasonable outcomes... without presupposing any narrow, controversial view of what the outcomes of democratic procedures should be, much as a good justification of a particular scientific research design does not presuppose the hypothesis that the research aims to test" (Ingham 2013, 136). Rather than establishing their empirical propensity to produce particular results, therefore, epistemic democrats emphasize structural features of democratic procedures; turning to abstract arguments, analogical reasoning, and —most centrally-formal proofs of collective competence (Schwartzberg 2015).

The simplest and most prevalent of these proofs-once called the "jewel in the crown of epistemic democrats" (List and Goodin 2001, 283) — is the Condorcet Jury Theorem (CJT). This theorem shows, roughly, that if many people independently make a binary decision that has a correct answer, and each has a greater-than-random chance of being correct, a majority vote is extremely likely to deliver the correct answer. Following its rediscovery in the late $20^{\text {th }}$ century, early epistemic democrats eagerly applied the theorem to democratic politics (Estlund 1994; Grofman and Feld 1988). 
In the years since this initial enthusiasm, however, the theorem's relevance for democratic theory has repeatedly been challenged (Anderson 2008; Christiano 1996, 33-34; Dietrich 2008; Gaus 1997), and even many former advocates have now conceded its limited usefulness (Estlund 2008, 223-36). The requirement that individual decisions be independent of one another, for instance, is incompatible with the deliberation and communication that many epistemic democrats understand as crucial to the superior performance of democratic procedures. In assuming a discrete number of choices, moreover, the CJT also ignores problems of agenda control (Fuerstein 2008). Perhaps the most devastating objection to the CJT's practical relevance, however, is simply that it proves too much (Ingham 2013). If we suppose the theorem does apply to actual democratic elections, we must implausibly conclude that they almost never deliver the "incorrect" result. Without this supposition, meanwhile, the theorem provides existing institutions with no defense against epistemic critiques.

As a result, contemporary epistemic democrats have typically looked elsewhere for proof of collective competence. Perhaps most prominently, Hélène Landemore has recently championed a theorem known as Diversity Trumps Ability (Landemore 2012; Landemore and Elster 2012). According to simulations run by Hong and Page (2004), a randomly selected group of problemsolvers will often outperform a group of the best individual problem-solvers, due to the beneficial effects of cognitive diversity. Since this theorem allows for deliberation, unlike the CJT-and furthermore does not assume a discrete number of choices - it is understandably attractive to epistemic democrats looking for a more realistic alternative.

Unfortunately, however, its validity also depends on highly restrictive conditions which cannot be assumed to hold in real political circumstances (Brennan 2016, 180-94; Thompson 2014; Van Hees 2007). Perhaps most importantly, it assumes cognitive diversity without value diversity, and 
once the latter is introduced, the theorem fails to show what Landemore claims (Ancell 2017). Moreover, she does not sufficiently address the possibility that epistocratic institutions could easily coopt this virtue. Indeed, Bell's model for a modernized Confucian political meritocracy foregrounds diversity in the selection criteria for leaders as well as active consultation of diverse bodies of citizens - in both cases building on existing CCP practices (Bell 2015, 190).

There are, of course, a range of other analogies and formal results that have been used to demonstrate the epistemic competence of democratic procedures, many of which rely on the value of cognitive, intellectual, or perspectival diversity. ${ }^{5}$ We may safely set them aside, however, given the objection just raised. After all, any epistemic advantages thought to be unique to democratic institutions could conceivably be coopted by a sufficiently well-designed epistocracy. Even if the multitude possesses some special wisdom that no team of experts could match, that is, competitive elections with universal suffrage are not obviously the most efficient way of harnessing it, and could conceivably be improved upon by clever experts.

Extant epistemic approaches, it seems, have failed to deliver on their promise to provide an instrumental defense of electoral democracy that is robust to challenges from epistocracy and other "benevolent dictator" objections. As the longtime epistemic democrat David Estlund admits in his recent work, it is no use denying that "there are subsets of citizens that are wiser than the group as a whole" (Estlund 2008, 40). The problem with epistocracy, rather, lies with deciding which subset to empower. Yet Estlund squanders this insight, in my view, by interpreting the problem in the terms of public justification, arguing that no epistocratic ruling class could be chosen which would be "justifiable in terms acceptable to all qualified points of view" (Estlund 2008, 41). As

\footnotetext{
${ }^{5}$ This logic is central, for instance, to Waldron's (1995) reading of Aristotle-who memorably analogizes democracy to a banquet with many contributors - as well as Estlund's parable of the blind men and the elephant, whereby the men succeed in correctly identifying the animal only by pooling their individual sense data (2008, 233-36). See also Bohman (2006).
} 
Landemore $(2012,52)$ laments, his account thus resorts once again to intrinsic concerns, relying on epistemic considerations only to show that democracy outperforms random selection of outcomes. Though the formal proofs she favors are unconvincing, therefore, she is right to insist that a robust, fully instrumental defense of democracy is possible.

Given the serious practical dangers of according political power on the basis of epistemic merit, I argue, we can readily meet epistemic critics of democracy on their own instrumentalist turf. To do so, however, we must reject the "epistemic frame" long preferred by democracy's critics, which proposes to compare democracy and epistocracy in terms of the wisdom of those supposed to have ultimate sovereignty - i.e., the demos and the knowers, respectively. Given that all regimes are in reality composed of complex, pluralistic power structures, the notion of "ultimate" sovereignty only obfuscates (see Pettit 2013, 12-15, 220-29). As I elaborate below, democracy and epistocracy are not diametrically opposed: in fact, successful democracies rely on certain epistocratic institutions, while the proposals of Brennan and Bell avowedly include democratic elements. Instead of evaluating the wisdom of the "sovereign" in each regime, therefore, I urge sustained attention to the incentives and opportunities facing those whose power is, in relative terms, most concentrated.

\section{Beyond the Epistemic Frame: Defending the Power of the Multitude}

My core argument proceeds in three parts, defending three central components of electoral democracy through an engagement with alternatives presented by three contemporary epistemic critics. I begin with the two epistocratic proposals discussed above, defending political competition against Bell's centralized political meritocracy, and universal suffrage against Brennan's franchise qualifications. In both cases, I admit that epistrocratic institutions could conceivably produce superior substantive outcomes, yet maintain that they are not worth the serious risks they entail. In 
practice, epistocratic mechanisms would be susceptible to especially dangerous forms of "capture" by rulers seeking to entrench their power, while their purported advantages are very unlikely to materialize. Despite the many deficits of competitive elections with universal suffrage, thereforeincluding their own vulnerabilities to entrenchment and capture-we have decisive reasons not to experiment with epistocratic alternatives.

I then consider the possibility of mitigating the pernicious effects of political ignorance by limiting the state's discretionary power, as might seem to be implied by my concern with state capture. Indeed, I argue, constraining and decentralizing political power can help to resist certain forms of entrenchment and capture, but it also enables others, and thus cannot represent a general solution. In particular, limiting the state's ability to counteract social and economic inequalities facilitates growing stratification and concentration of private power, which almost inevitably feeds back into the political process. In the long run, that is, certain limits on discretionary power will turn out to be self-undermining, allowing the growth of powerful entities or factions that may rival and eventually capture the state apparatus. Rather than simply minimizing the state's discretionary power, I conclude, we must balance "defensive" strategies of constraint and decentralization with equally necessary "offensive" projects, which use state power to curtail and redistribute this dangerously concentrated private power.

To supporters of each of these proposals, my conclusions will likely seem hasty, and there is certainly more to say in each case. My primary aim in this essay, however, is not to convince committed epistocrats—indeed, I expect most readers already share my practical commitment to electoral democracy. As noted above, my goal is of a higher order: I aim to sketch an integrated theoretical paradigm for explaining and defending that commitment amid growing doubts about its intellectual foundations and mounting challenges to its practical supremacy. The account of 
electoral democracy I present is more compelling than the alternatives, I suggest, because it responds to epistemic critiques and "benevolent dictator" objections without relying on intrinsic concerns, Churchillian complacency, or the dubious analogies and formal results employed by epistemic democrats.

As should be clear, the concept of "state capture" is central to this account, though its role is perhaps unconventional. Rather than explaining why certain outcomes are undesirable, the term functions in my argument to highlight similarities between different outcomes that are antecedently accepted as bad: namely, that all involve the use of state power by a particular faction to achieve its partial ends at the expense of other groups. Applying such a normatively laden concept to particular cases will inevitably generate disagreement, of course, but there are plenty of uncontroversial cases — ranging from slavery and tyranny to regulatory capture — and my argument proceeds largely from these cases. Indeed, I prefer to see state capture as a family resemblance concept, rather than as a set of necessary and sufficient conditions. Regardless, the concept anchors my defense of all three components of electoral democracy, and thus provides a genuine, comprehensive alternative to the prevailing intrinsic and instrumental theories that I set aside or rejected above. Instead of purporting to achieve an intrinsically valuable form of collective selfrule or an instrumentally valuable form of collective wisdom, electoral democracy emerges in the following sections as a limited yet indispensable tool for resisting particularly dangerous forms of state capture.

\section{Political Meritocracy and the Necessity of Competition for Power}

We may begin with Bell's (2015) arguments for political meritocracy. Despite what many assume from his book's title (i.e., The China Model), Bell does not claim that the contemporary Chinese government fulfills the meritocratic ideal, nor even that it outperforms existing electoral 
democracies (19). Instead, the version of political meritocracy he proposes as a "model" will have eliminated the political repression and corruption characterizing the current regime by implementing independent checks on centralized power $(116,124,150)$, a freer press $(134,174)$, intraparty competition (138), more democratic participation in local affairs (169, 189-191), improved Confucian moral education (124), greater economic equality (132), and diversified methods of meritocratic selection (130,135, 193-194), among other reforms. Top-level leaders in Bell's imagined political meritocracy, in other words, would be prevented from abusing their power by a number of norms and institutions that many will recognize as liberal. Citing precedents from East Asian history and philosophy, however, Bell rightly observes that many of these devices are not exclusively Western or liberal in origin. Notably, this includes meritocracy itself, which has origins in both Western and Confucian traditions as a mechanism for constraining the power of the nobility and other privileged elites (65-66).

Bell's emphasis on independent checks on centralized power is not surprising. The evils of unconstrained authoritarian rule—or, more classically, tyranny-have long been obvious to all serious observers. As the power of modern centralized states has continued to expand, moreover, effective constraints have only become more important (El Amine 2016). Even if unconstrained rulers are initially benevolent, the political institutions they create can be used by less benevolent successors (or usurpers) in tremendously harmful ways. Meanwhile, opposition leaders have no feasible non-violent path to power, and are thus more likely to engage in violent resistance; inducing coercive repression and/or civil war (Przeworski 1999). Finally, the absence of independent constraints is associated with "extractive" institutions and reduced long-run economic growth (Acemoglu and Robinson 2012; Fukuyama 2014; North, Wallis, and Weingast 2009). 
Like most historical advocates of rule by the few, therefore, contemporary epistocrats happily concede that rule by unconstrained, extractive elites is worse than rule by the many. They insist, however, that non-democracies are not necessarily tyrannical in this way. As Bell points out, for instance, the leaders of contemporary China and Singapore are already constrained by a range of norms and institutions, and his reforms would constrain them further. Moreover, effective constraints predated competitive elections in most early liberal states, while implementing elections without supporting reforms in certain contemporary non-democracies could be counterproductive. As a result, I readily concede that elections need not always be our first practical priority.

What I maintain, however, is that no large-scale, long-term political vision is plausible without open political competition. Within democracies, suspending elections may be necessary when the electoral framework itself faces an existential threat, but this measure must always be temporary (Kirshner 2014). Meanwhile, non-democracies should generally strive to achieve stable electoral institutions as quickly as realistically possible. This is not because elections are intrinsically valuable, nor because they always yield superior outcomes. Instead, the primary reason political meritocracy does not present an attractive alternative to electoral democracy is that it is far more likely to lead to unconstrained authoritarianism or tyranny. Though constraints on centralized power can also be eroded in a system with electoral competition, the magnitude of this risk is much greater under political meritocracy—even given highly advantageous conditions — than it is under any ordinary consolidated democracy. The key difference is that meritocratic leaders have much more effective tools for entrenching their power.

In any political system, many things influence whether incumbents and their factional allies retain power. In both meritocracies and democracies, for instance, the approval of a broad class of 
economic and cultural elites is an important contributing factor. In both systems, similarly, massive popular discontent bodes poorly for incumbents. In any political meritocracy, however, the incumbents themselves - as those atop the centralized meritocratic hierarchy-have far greater capacity to affect the outcome. Given the significant discretion afforded by the unavoidably ambiguous standard of political "merit," incumbents can gradually shift the balance of power in their favor, appointing cadres at every level who will support their factional interests, and replacing those who will not. ${ }^{6}$ Compared with elected democratic politicians, therefore, they have far more latitude in shaping the structural conditions supporting their own political power, and (consequently) much greater capacity to entrench their rule.

Of course, democratic incumbents also use their control over the state apparatus to increase their chances of retaining power-reliably employing techniques such as gerrymandering, for instance, where available. They may also attempt to capture independent agencies by appointing factional allies or undermine the economic and organizational foundations of opposition parties (see Levitsky and Ziblatt 2018, 72-96). Yet there are at least three crucial factors restraining such efforts at entrenchment: the uncertainty of electoral outcomes, the organizational strength of the opposition, and independent commitment to the institutional framework of liberal democracy.

First, incumbents know that despite their efforts to stack the deck, their opponents may yet come to power and retaliate. Given sufficient uncertainty about the results of subsequent elections, an equilibrium in which all incumbents respect certain limits to such self-serving strategies is beneficial for all parties (Przeworski 1991, 2005; Shapiro 2016, 49-50). ${ }^{7}$ Attempts to exceed these

\footnotetext{
${ }^{6}$ There is evidence that this is precisely what Xi Jinping did, for instance, with his "anti-corruption" campaign (Hualing 2015; Yuen 2014) — setting the stage for his recent move (in February 2018) to do away with term limits and further consolidate his power.

${ }^{7}$ My argument thus reinforces the utility of regime classification schemes based on electoral competitiveness (e.g., Levitsky and Way 2010, 5-16), whereby full democracies are characterized by an even playing field and significant electoral uncertainty, non-democracies by a lack of meaningful competition, and hybrid regimes by a skewed field that nevertheless retains some uncertainty.
} 
limits may then be foiled by independent power centers within the state—-perhaps through conflict between executive and legislative branches, as Madison famously envisioned, or perhaps through other mechanisms like judicial and bureaucratic independence, federalism, and institutionalized protections for opposition parties. As Levinson and Pildes (2006) insist, the key principle is "separation of parties"- the distribution of state power among different factions-rather than the separation of powers as such (which is perfectly compatible with unified partisan control). Second and more generally, then, rival parties will be able to coordinate opposition to incumbent entrenchment-at the limit including armed rebellion. Indeed, the organizational strength of opposition parties is one of the key conditions for achieving and consolidating democracy (Levitsky and Way 2010, 68-70).

Finally, these incentives will be supplemented by some degree of genuinely principled commitment to liberal democracy and the rule of law-especially among those with strong professional socialization such as lawyers and journalists. This commitment will bolster the existing motivation of opposition officials to frustrate incumbent entrenchment, for instance, as well as any existing preferences for stable equilibrium among the incumbents' allies. Indeed, mechanisms grounded solely in political incentives would undoubtedly be less reliable in the absence of genuine principled commitments, and their significance should not be discounted. At the same time, polarization reliably weakens their motivational force relative to immediate substantive concerns (Svolik n.d.). Perhaps even more troublingly, it can be difficult to disentangle principled from expedient motives in the first place (Bagg 2018a, 2018b; Lodge and Taber 2013). Given these vulnerabilities, it would be unwise to rely entirely on the production of principled commitments through education and socialization to maintain the integrity of notoriously fragile constraints on centralized power. 
That, however, is precisely what Bell's political meritocracy would do. Even if the independent power centers he proposes were initially effective, their continued independence would not be supported by electoral uncertainty and organized opposition, and could be relatively easily coopted by top-level leaders disposed to do so. As Bell himself concedes (123-124), the stability of constraints on power in a meritocracy ultimately relies on the forbearance of those at the top of the centralized hierarchy, which he proposes to secure through improved Confucian moral education.

As I have emphasized, I do not deny the efficacy of such principled commitments. Yet as Madison famously insisted, "enlightened statesmen" should not be relied upon to sustain crucial constraints on power in perpetuity. ${ }^{8}$ Without reinforcement from strong independent incentivessuch as those provided by institutionalized uncertainty and the separation of parties-principled commitment to maintaining independent power centers will eventually succumb to the siren song of political expediency. Institutions which foster legitimate opposition and open competition for power thus render the capture of the state by tyrannical, extractive elites less likely than institutions which effectively allow incumbents to select their own replacements. ${ }^{9}$

In my view, the severity of this danger is more than enough reason to abandon the idea of political meritocracy. It is also worth noting, however, that the increased risk of tyrannical rule is not offset by great prospective rewards. Even when incumbents do not actively consolidate power,

\footnotetext{
${ }^{8}$ See Andrew Nathan (2016, 155), who contests Bell's "perfected" conception of human nature, and (citing Madison) expresses doubt that "any political system can be induced to operate on the basis of moral virtue alone." Lynette Ong (2016) voices similar concerns.

${ }^{9}$ I make no distinctions here between democratic institutional frameworks-for example, parliamentarism versus presidentialism - but three observations are relevant. First, a variety of competitive systems could conceivably generate the sort of incentives which sustain independent checks. Second, the strength of these incentives should be a primary consideration in choosing between systems. Third, this is likely quite context-dependent, making it difficult to draw general conclusions. That is why, despite clear affinities with Ian Shapiro's $(2003,2016)$ approach, I do not share his confidence in pure majoritarianism, which seems to depend on overly optimistic assumptions about retrospective accountability (see Achen and Bartels 2016, discussed below).
} 
they will still be subject to more mundane forms of capture and corruption, undermining meritocracy’s claim to possess significant advantages over democracy.

Consider the strict conditions enabling the progress of natural science-perhaps the most obviously successful meritocracy in existence. Especially within Kuhnian "normal science," standards of merit are relatively uncontroversial. Where disagreement exists, it is usually resolved methodically within structures of open competition, which are themselves supported by a "polycentric" disciplinary structure. Finally, few scientific questions have significant consequences for the distribution of social power, meaning that scientific institutions are rarely targeted for "capture" by outside interests.

In politics, by contrast, the distributive stakes are far higher. Political meritocracies are thus, predictably, the target of intense competition for capture among factions seeking to advance their interests. Given the inevitable limits to open competition under a centralized hierarchy, these factions are forced to displace the weight of their political disagreements onto the definition and application of meritocratic standards. Yet these standards are far more ambiguous than those of science - thanks partly to wider disagreement on the ultimate ends to be served (Jenco 2016) and consequently less capable of withstanding such strain. Though scientific meritocracies have enabled remarkable progress through the methodical resolution of disagreements, therefore, this is only in virtue of several features that cannot be replicated by a centralized political meritocracy. ${ }^{10}$

Despite these vastly more favorable conditions, of course, even science is hardly a perfect meritocracy. From its origins to the present, systematic biases and exclusions have profoundly affected its character (Longino 2013; Marks 2009). In other realms where it is often invoked, meanwhile, the ideal of meritocracy is even further from realization, and is often simply used to

\footnotetext{
${ }^{10}$ For a more detailed discussion of this analogy, see Bagg (2018b, 269-73).
} 
legitimize unjust inequalities (McNamee and Miller 2013). These challenges do not render the concept of meritocracy incoherent or inherently reactionary — on the contrary, meritocracy is a necessary feature of any modern political system, including electoral democracy. Yet no meritocracy is immune to bias, capture, or corruption (Fricker 2009; Medina 2012), and given the intense strains they must bear, such defects will be especially significant in political meritocracies.

Acknowledging the extensive corruption of China's existing political structure, Bell often draws on the success of political meritocracy in Singapore and Hong Kong to demonstrate that these flaws might be remedied $(31-33,113,117)$. According to many other scholars of the region, however, the opposite trend is more likely. Political meritocracy in Singapore and Hong Kong is already decaying, they observe - and will continue to do so, absent democratization-while China's is unlikely to become less corrupt (Hui 2015, 2016; Tan 2008). Ironically, they conclude, meritocracies function best under democratic political conditions.

That said, we need not deny that political meritocracies can govern well-perhaps even outperforming electoral democracies in certain cases. Rather, my claim here is that political meritocracies are unlikely to enjoy either systematic or substantial advantages over comparably situated electoral democracies in the long run-especially those which successfully integrate healthy meritocratic institutions at other levels. Given this, the increased risk of authoritarian consolidation easily counts as a decisive argument against political meritocracy.

\section{Franchise Qualifications and the Necessity of Universal Suffrage}

We turn next to the franchise qualifications proposed by Brennan (2016, 204-30; see also Caplan 2007, 197-98). He acknowledges the injustice of historical restrictions grounded on morally irrelevant factors such as race, sex, or possession of property. Given the epistemic flaws of democracy, however, he asks: why not conditionalize suffrage upon morally relevant epistemic 
qualifications? Prospective drivers must pass a driving test, and prospective doctors must attend medical school. Why not issue voting licenses in a similar way, through competence testing or educational requirements?

As above, my response to these suggestions is thoroughly pragmatic. While conceding the conceptual possibility of unobjectionable epistemic qualifications, I highlight the practical risks of giving political leaders the power to design them. Though not quite as dangerous as the ability to appoint successors directly, the ability to implement epistemic qualifications would also enable incumbents to entrench their rule- and the hypothesized benefits here are even less likely to materialize. Thus, Brennan's epistocracy ought to remain off the table as well.

Of course, democracies already enable incumbents to manipulate the pool of eligible voters in various ways. Some restrictions, like those concerning age and citizenship, are likely inevitable. Others, however-including voter identification requirements, felon disenfranchisement, and the gerrymandering of single-member districts - are routinely used to entrench the power of incumbents by tilting the electoral odds in their favor (Levitsky and Ziblatt 2018, 183-86, 20811). Such policies are typically justified on other grounds, and some may be valuable on balance, yet in each case, this feature gives us reason to be suspicious (Issacharoff and Pildes 1998; Shapiro 2016, 86-88). By comparison, then, Brennan's proposals would grant politicians far greater leeway in choosing their own voters, and should be regarded as far more dangerous.

Consider the possibility of conditionalizing suffrage on educational attainment. Brennan himself speculates $(2016,223)$ that in the US, Democrats would favor very low or very high qualifications, while Republicans would prefer a mid-range qualification, such as a high school diploma. Yet he fails to recognize what a dramatic effect this could have: for either party, implementing a properly targeted policy would instantly translate a small temporary majority into 
a massive and durable electoral advantage. Where traditional gerrymandering faces natural limits, moreover-imposed by the need to distribute a fixed voting population among geographically contiguous districts_-"epistemic" gerrymandering could continuously compound incumbent advantages through ever-more-targeted tests, recursively altering the voting population itself. Even if their immediate effects were not so extreme, finally, such policies would still give incumbents strong incentives to manipulate educational attainment patterns for partisan ends.

Implementing a competence test presents no solution, as incumbents would have similarly strong incentives (and even greater leeway) to manipulate its content. Once established, moreover, parties would likely scramble to prepare their supporters, much as they already conduct voter registration drives and get-out-the-vote campaigns in places without automatic registration and mandatory voting. ${ }^{11}$ The resulting arms race to "teach to the test" could hardly be expected to yield substantial benefits in vote quality - indeed, given the massive expenditures required, the most significant consequence would be to intensify parties' dependence upon concentrated wealth.

Brennan concedes that his proposals could have drawbacks, including the potential for manipulation (222-230). However, he asserts that they also promise vastly superior outcomes. Caricaturing any unwillingness to experiment with epistocracy as a species of Burkean conservatism, he insists that we cannot know in advance whether such tradeoffs will be worthwhile. I disagree. As I have already argued, we know enough about politicians to predict that some would use these tools to entrench their power. Perhaps more importantly, we also know enough about voters to predict that disenfranchising those with low political knowledge would not

\footnotetext{
${ }^{11}$ The fact that literacy tests in the US South did not generate a similar arms race reflects their peculiarly pernicious, openly partisan nature. Since white voting rights were generally "grandfathered" in, only blacks were subject in practice to the tests, which were designed to be nearly impossible. Meanwhile, those who managed to pass were often prevented from voting by other means. Under such conditions, mass mobilization by Republicans would have been futile.
} 
substantially improve the epistemic quality of electoral results. Thus, even if incumbents (or independent bodies) imposed perfectly benign epistemic qualifications, the benefits Brennan projects would be very unlikely to materialize.

Consider that voters in modern democracies do not choose directly between different policies. Instead, they choose between parties or candidates. There is thus substantial distance between a voter's overall level of political knowledge and the quality of her vote choice. Yet Brennan makes very little effort to demonstrate that higher political knowledge scores would be associated with greater likelihood of voting for the "correct" party or candidate. ${ }^{12}$ Instead, he relies on an intuitive sense that political knowledge must raise vote quality. ${ }^{13}$

Perhaps, on the margin, it does. As Brennan himself insists throughout his book, however, our intuitive understanding of voting behavior cannot be trusted. In particular, it seems, rational assessment of the arguments for competing policies - which political knowledge tests purport to measure-plays a small role (at best) in vote choice. As extensive research on "motivated reasoning" has demonstrated, better information rarely changes our mind, it simply gives us better tools for defending our intuitions (Lodge and Taber 2013). Meanwhile, education primarily alters our policy preferences indirectly, by changing our social context and identity. Where they exist, then, correlations between political knowledge and vote choice are largely explained by unrelated, non-rational factors - centrally including the set of identity groups to which we belong (Achen and Bartels 2016). By far the most significant consequence of disenfranchising those individuals with

\footnotetext{
${ }^{12}$ We need not assume that political questions have objectively correct answers in order to accept that elections present citizens with options that are, in some sense, better than others.

${ }^{13}$ Brennan does cite two studies correlating high information with a smattering of broadly libertarian preferences that he presumably considers correct (33-34). While these studies control for certain demographic variables, however, other potential confounds remain (e.g., group identities elided by crude demographic controls). More importantly, they do not establish that having such "superior" policy preferences actually enhances vote choice.
} 
low epistemic qualifications, therefore, would be to disenfranchise the (already disempowered) groups to which they disproportionately belong.

Brennan glibly dismisses this “demographic objection.” He announces repeatedly, for instance, that by his "objective," "morally relevant" standards, black women are the least "competent" voters in the US, and that his proposals would therefore disenfranchise them in large numbers (33, $132-133,148,227-228)$. Rather than taking this opportunity to re-examine his epistemological premises, however, he assures readers of his excellent implicit bias scores, and asserts that disadvantaged citizens cannot vote in ways that promote their interests "unless they have tremendous social scientific knowledge" $(227) .{ }^{14}$ Remedying their disadvantages thus requires disenfranchising them — and thereby entrusting their interests to better-informed voters. ${ }^{15}$

Such claims are, quite frankly, preposterous, and one may be tempted simply to ignore them. In my view, however, it is worth showing why they are not supported by the empirical evidence Brennan cites, since this research does challenge many common assumptions about democracy, and it should not be dismissed along with Brennan's conclusions. It is well established, for instance, that most voters know too little about policy to make meaningful choices between parties on that basis - meaning that there is no "bedrock" of public opinion to which representatives might faithfully respond (Disch 2011). According to Achen and Bartels (2016), moreover, the minimalistic model favored by many political scientists—retrospective accountability—is also typically oversold (146-176). At best, it seems, voters hold representatives accountable for a fairly

\footnotetext{
${ }^{14}$ One might suggest that a more relevant measure of epistemic merit is one's likelihood of voting for a know-nothing authoritarian populist-implying that black women were the most competent demographic group in the 2016 US Presidential election - but I will not pursue that argument here.

${ }^{15}$ On most of Brennan's proposals, this would entail entrusting the interests of the poor, women, and African Americans in the United States to rich white men. To preempt the obvious objections, he proposes that worries about fairness could be resolved by giving extra weight to the votes of those demographic minorities who do qualify to vote. Even if we grant (implausibly) that this solves the problem, however, it does so only by exacerbating another: clearly, entrusting electoral outcomes to complex algorithms only widens the opportunity (and incentive) for manipulation.
} 
narrow set of outcomes (Healy and Malhotra 2013); at worst, for nothing at all—or for outcomes representatives cannot control. This research thus warrants serious attention, if not a thorough rethinking of democratic theory (e.g., Green 2009). Yet even the most resolutely skeptical accounts do not remotely imply that low-knowledge voters would be better off disenfranchised.

For one, democratic realists like Achen and Bartels readily admit some correspondence between public opinion and policy outcomes. So long as they must fear electoral defeat, incumbents will adhere to "vague limits of permissiveness" set by public opinion, and though electoral punishment of specific misdeeds is rare, it does occur in extreme cases (Achen and Bartels 2016, 318-19). Uncertain about what will tip the balance from victory into defeat, politicians carefully manage their reputations, aiming to satisfy a range of interest groups without upsetting others too profoundly (Oppenheimer and Edwards 2012, 206-18). Even if the franchise does not meaningfully empower individuals, therefore, it does give non-negligible leverage to groups.

That said, we may grant that enfranchisement often brings surprisingly few benefits. For instance, $19^{\text {th }}$-century socialists and reactionaries both assumed working class suffrage would yield far more extensive redistribution than it did. We may also grant that most voters are sociotropic, meaning that their votes are directed at a common good, rather than their own self-interest. Yet even Brennan acknowledges that there is clearly some connection between enfranchisement and group interests, observing for instance that "if we deprive all black people of the right to vote... this will help facilitate people of other races in exploiting, dominating, and oppressing blacks" (9798). Nothing could be more obvious, of course, but given Brennan's assumptions, it cries out for explanation: why might this be? Alas, it seems, not everyone votes sociotropically — and even when we do, our views of the "common good" are inevitably biased (Bagg 2018b). 
In sum, empirical research in public opinion and political psychology does not dispute that groups - even those with below-average political knowledge - can use the electoral system to advance their interests. What the research does throw into question is the rational grounding such processes are often supposed to have. If "most citizens support a party not because they have carefully calculated that its policy positions are closest to their own, but rather because 'their kind' of person belongs to that party" - as Achen and Bartels $(2016,307)$ summarize-members of disadvantaged groups may not always vote in ways that promote their interests. This is concerning, if unsurprising. Yet it hardly implies that their voting behavior is entirely insensitive to their interests - much less that their interests will be more reliably protected by others. Voters driven by identity rather than policy will effectively promote their interests as long as the identities they find salient lead them to support parties and candidates whose policies promote their interests.

To be sure, this is not always the case. But neither is it particularly implausible-voters do not choose their identities at random—and it seems especially likely when groups suffer collective disadvantages which render that identity affiliation salient. In such cases, ordinary group members will often follow the recommendations of respected leaders, many of whom would pass any epistemic qualification Brennan could propose. Because this compliance is largely driven by identity rather than informed and independent consideration of the issues, of course, leaders have latitude to extract rents and engage in various deceptions. Voter ignorance does have real costs. Barring exceptional circumstances, however — such as a sinister conspiracy among group leaders-it need not render their votes counterproductive, as Brennan suggests. Perhaps workingclass voters could have done better than the social democratic parties of the early $20^{\text {th }}$ centuryjust as contemporary African Americans could do much better than the Democrats—but it is idle to pretend that such allegiances have no basis whatsoever in genuine protection of group interests. 
We may admit, then, that members of disadvantaged groups often vote in suboptimal waysjust like everyone else. As we have seen, however, it is highly unlikely that instituting epistemic conditions on the franchise would reliably and significantly improve average vote quality. It is far more likely that they would be used to entrench the power of incumbents-potentially so effectively as to endanger the competitiveness of elections. Restricting the political rights of lowknowledge disadvantaged groups, therefore, would bring risks for those groups (and for the polity as a whole) that are far out of proportion to any hypothesized benefits. Insofar as Brennan's epistocratic proposals are intended for the real world, we must resoundingly reject them.

\section{Limited Government and the Necessity of Robust Discretionary Power}

We turn, finally, to the idea of limited government: i.e., constraining and decentralizing political power through mechanisms like federalism, local governance, and judicial review, while encouraging greater reliance on competitive markets and interjurisdictional foot-voting. As Ilya Somin argues, this could "reduce the problem of public ignorance by reducing the number of issues to be decided by government to a level which voters would find more manageable" $(2013,141$; see also Caplan 2007, 192-197). Indeed, something like this solution may appear as the logical extension of my argument: if epistocracy is dangerous because it enables state actors to accumulate excessive centralized power, perhaps the solution is to place tighter constraints on those actors.

As I demonstrate, however, the problems of entrenchment and capture are not so easily resolved. While certain limits on discretionary state power are advisable, others would actually facilitate the entrenchment of various elites, and ultimately the capture of the state itself. Thus, I argue that resisting state capture requires a delicate balance between "defensive" strategies that limit the state's discretionary power, and "offensive" strategies that use this discretionary power to target the potential perpetrators of capture-i.e., the possessors of concentrated private power. 
Consider first that even a "minimal" state—one constitutionally limited, perhaps, to defining and enforcing property rights—-would still play a crucial role in the distribution of power, and would hardly be neutral between differently situated actors. Such a state would enable privileged elites to perpetuate their social and economic advantages quite effectively, while coercively preventing any redistributive efforts-legal or extra-legal—undertaken by coalitions of the disempowered. More generally, state protection of private property is fundamental to the social order in nearly all modern societies, and within this context, rules or structures prohibiting centralized redistribution between groups will predictably facilitate the entrenchment of elite power. Accordingly, such limits can be considered mechanisms of state capture.

Advocates of limited government may object to this description. Even if elites benefit disproportionately from state protection of property, they do not have arbitrary control over state action. Given a situation of highly asymmetrical social power, indeed, it might seem that increasing the state's centralized power would only give elites more powerful tools with which to dominate others. We should not brush this concern aside, given that discretionary state power has often been used in precisely this way (e.g., Somin 2015). Nevertheless, historical experience also provides evidence of opposing tendencies.

In the infamous Lochner era between 1897 and 1937, for instance, the US Supreme Court repeatedly overturned redistributive legislation favored by wide majorities. Interestingly, some justices saw themselves as defending the "general" interest—namely, economic growth—against labor's attempts to capture the state in service of its "partial" interests (Rahman 2016, 64). In hindsight, however, it is far more plausible to understand these conservative justices as agents of state capture, defending the partial interests of industrial capitalists at the expense of nearly everyone else. For one, growth inevitably creates winners and losers, and cannot be understood as 
a "neutral" policy that is always in the "general" interest. Meanwhile, labor's eventual victories did not demonstrably slow growth, and in fact seemed to facilitate widely shared prosperity. Of course, "state capture" is no more self-interpreting than any other normatively laden concept, and as I've acknowledged, there will always be disagreement about how to apply it in practice. Nevertheless, it is broadly accepted that Lochner-era jurisprudence protected the interests of a small economic elite at the expense of a vast majority (Sunstein 1987).

Nor is it the only example of US elites employing techniques of "limited government"-i.e., constraining and decentralizing political power-to entrench their dominance. Southerners have long appealed to federalism in defending the institutions of white supremacy, for instance, while metropolitan elites routinely use the principle of local governance to thwart the efforts of disadvantaged groups to claim a greater share of regional resources (Anderson 2010; Hayward 2013). Here too, of course, opponents of redistribution by centralized federal or municipal authorities may claim that it represents a pernicious form of state capture-and here too, their claims are thoroughly implausible. Though the federal government coercively imposed the Civil Rights Act upon states, for instance, few today would dispute that it was the state-level Jim Crow laws overturned by the Act which more clearly embodied the use of coercive centralized power by a privileged class to perpetuate its (perceived) interests at the expense of others.

The point of these examples is not to show that limits on discretionary power are always mechanisms of state capture. As Somin and others correctly observe, constraining and decentralizing political power can often make capture more difficult or less consequential. Meanwhile, there is much to be said for democratic empowerment through "exit" rather than "voice" (Warren 2011). As these examples show, however, limiting state power can also serve to enable dangerous forms of elite entrenchment. In particular, when popular efforts to counteract 
social and economic inequalities are routinely foiled by privileged classes using tools like judicial review, federalism, and local governance, their ability to prevent centralized redistribution certainly looks suspiciously like arbitrary control of the state.

Regardless of whether we extend the concept of "state capture" to this kind of obstruction, moreover, the increasing concentration of private power it enables will often be used to perpetrate capture in even more straightforward ways. As the social and economic power of privileged classes, interest groups, corporations, and individuals continues to grow, their political clout will inevitably expand as well. Once they become powerful enough, no well-intentioned constraints will effectively prevent them from using the state to implement what Lindsey and Teles (2017) call "upward redistribution." If a state's commitment to strict limits on its discretionary power prevents it from resisting the rise of such actors, therefore, this commitment will ultimately prove self-undermining. ${ }^{16}$ To stipulate otherwise is to engage in the sort of wishful thinking characteristic of central planners who assume incorruptible state agents, or meritocrats who rely on moral education to sustain independent power centers.

As a result, a state seeking to resist capture must not only "play defense" by means of selfimposed limits on their discretionary power, which can enable rampant concentration of social and economic power, in turn creating private actors and privileged classes with dangerous capacities to perpetrate capture. ${ }^{17}$ In addition, it must go on the offensive, undermining these threats before they become impossible to resist. A state that merely refrains from perpetuating oligarchy or racism - without proactively combating these systemic forces-will become their instrument eventually.

\footnotetext{
${ }^{16}$ Militant democrats have long made this observation about principles such as toleration (Kirshner 2014), but few have noted that it applies to limits on state power as well.

${ }^{17}$ As Tilly (2007) shows, democratization normally requires substantial state capacity, because weak states are far more vulnerable to capture and/or subversion by powerful private interests.
} 
What might constitute an appropriate balance between offensive and defensive strategies? Drawing on Progressive-era thinkers like Louis Brandeis, Sabeel Rahman (2016) outlines a promising approach that avoids the pitfalls of both "laissez-faire" and "managerialist" solutions, applying it to the important question of financial regulation. Rather than letting markets run riot or engaging in capture-ripe fine-tuning of their daily operations, he argues, "structuralist" regulation would seek to eliminate the shared interests enabling financial giants to collude and capture regulators in the first place - perhaps by separating commercial and investment banking, for instance, or breaking up structurally important firms. In combination with non-electoral modes of democratic oversight, Rahman claims, this will allow us to minimize capture within the regulatory state while retaining crucial capacities for prophylactic action against concentrated private power.

My aim in this section, of course, has not been to defend any particular configuration of "offensive" and "defensive" strategies for resisting state capture - such as that proposed by Rahman — but simply to show that some such balancing act is necessary. Discretionary state power may be dangerous, but so are many of the limitations often proposed as solutions. As a result, some gambles will inevitably be lost. Some expansions of state prerogative intended to curb concentrated economic power, for example, may ultimately strengthen the oligarchs' position. But surrendering the ability to take such prophylactic action is both unnecessary and ultimately counterproductive. Though some constraint and decentralization is advisable, it cannot represent a general solution to entrenchment and capture.

\section{Conclusion: An Appropriately Enthusiastic Appraisal of Electoral Democracy}

Recent years have witnessed growing controversy over the wisdom of the multitude. As epistemic critics drawing on a wealth of empirical evidence have cast doubt on the political 
competence of ordinary citizens, epistemic democrats have offered a defense of democracy grounded largely in analogies and formal results. In my view, the critics have been far more convincing. Nevertheless, I believe that electoral democracy can be defended on instrumental grounds, and in this essay, I have demonstrated an alternative approach. Instead of championing the peerless wisdom of average voters, I have shown that competitive elections, universal suffrage, and discretionary state power all disable potent mechanisms of elite entrenchment. Though the institutions of electoral democracy do not grant the demos ultimate sovereignty, they do reserve particular forms of power for the multitude of ordinary citizens, thus making democratic states more resistant to dangerous forms of capture than non-democratic alternatives.

The most important function of competitive elections, first of all, is not to enable popular authorization of law, nor to aggregate widely dispersed information, but to prevent incumbents from undermining independent constraints on their power. Given significant uncertainty about electoral outcomes and the presence of strong opposition, I have argued, democratic incumbents are more likely to exhibit restraint than their peers in non-competitive systems. So long as they must fear electoral defeat, more substantively, their actions will be tethered (albeit very loosely) to public opinion. Though hardly realizing the classical dream of collective self-rule, elections provide some leverage over leaders, as well as non-violent means for overthrowing would-be tyrants.

The point of universal suffrage, similarly, is not to give individuals an equal say over collective decisions, nor to reap the elusive benefits of diversity, but to prevent incumbents from manipulating suffrage restrictions to entrench their power. Though the franchise does not meaningfully empower ordinary citizens as individuals, it does make politicians think twice before ignoring the shared interests of the groups to which they belong. While hardly a sufficient 
safeguard of the interests of all groups, this ensures that all groups have some access to whatever minimal leverage is provided by competitive elections. If groups sometimes use this leverage in suboptimal ways, this hardly implies that their interests would be more reliably protected by others.

Finally, democratic states must have substantial discretionary power, but not because popular sovereignty is sacred, nor because popularly elected leaders are likely to use that power especially well. Indeed, certain limits are necessary to prevent entrenchment and capture. Yet othersnamely, constraints on redistribution-may represent forms of capture themselves. By frustrating efforts to rectify inequality and curtail concentrated private power, for one, such constraints facilitate the perpetuation of social and economic hierarchies. These, in turn, feed back into the political system, ultimately enabling more active, straightforward forms of capture. Here again, frustrating dangerous elite entrenchment requires granting greater power to the multitude.

What emerges from these concerns is an integrated theory of electoral democracy-i.e., as a limited yet indispensable tool for resisting state capture—which accurately appraises its value. On the one hand, my account offers historically robust, broadly convincing reasons for unwavering support of competitive elections, universal suffrage, and discretionary state power. In the face of mounting challenges on both theoretical and practical fronts, it thus fulfills a real need. On the other hand, few could mistake my account as naïve or complacent. It refuses to ignore the overwhelming empirical evidence of the epistemic deficits of ordinary citizens, or downplay the extent to which many existing democracies are already substantially captured by various elites, and thus offers a sober view of electoral democracy's limitations. Following the evidence, moreover, it suggests that many traditional proposals for improving the quality of collective decisions within electoral democracy—including education, deliberation, and more direct popular participation - will turn out to be less useful than democratic theorists commonly suppose. 
Far from encouraging pessimism, however, the point of this reality check is to suggest new priorities, setting a more productive political agenda for those interested in meaningful popular empowerment. Rather than striving to perfect electoral democracy through tighter correspondence between public policy and a better informed, more deliberative, more equally constituted public opinion, we should emphasize other registers of the democratic ideal. First, I have suggested, we must proliferate non-electoral modes of accountability and countervailing power, like the randomly selected oversight bodies proposed by Rahman and others (e.g., Guerrero 2014). Even more importantly, we must pursue more radical redistribution of social and economic powerboth through maximally capture-proof centralized policies like unconditional basic income, and through decentralized organizing and action (e.g., Phulwani 2016; Stout 2012). Once we take our focus off of elections as the singular site of democratic sovereignty, I conclude, we open ourselves to a far more expansive ideal of democracy. 


\section{References}

Acemoglu, Daron, and James Robinson. 2012. Why Nations Fail: The Origins of Power, Prosperity, and Poverty. New York: Crown Business.

Achen, Christopher H., and Larry M. Bartels. 2016. Democracy for Realists: Why Elections Do Not Produce Responsive Government. Princeton: Princeton University Press.

Ancell, Aaron. 2017. “Democracy Isn’t That Smart (but We Can Make It Smarter): On Landemore's Democratic Reason.” Episteme 14(2): 161-75.

Anderson, Elizabeth. 2007. "The Epistemology of Democracy." Episteme: A Journal of Social Epistemology 3(1): 8-22.

—. 2008. "An Epistemic Defense of Democracy: David Estlund's Democratic Authority." Episteme: A Journal of Social Epistemology 5(1): 129-39.

- 2010. The Imperative of Integration. Princeton: Princeton University Press.

Arneson, Richard. 1993. "Democratic Rights at National and Workplace Levels." In The Idea of Democracy, eds. David Copp, Jean Hampton, and John Roemer. Cambridge: Cambridge University Press, 118-48.

- 2004. "Democracy Is Not Intrinsically Just.” In Justice and Democracy: Essays for Brian Barry, eds. Keith Dowding, Robert Goodin, and Carole Pateman. Cambridge: Cambridge University Press, 40-58.

Bagg, Samuel. 2016. "Between Critical and Normative Theory: Predictive Political Theory as a Deweyan Realism.” Political Research Quarterly 69(2): 233-44.

_ 2017. "What Makes a Political Theory Political? A Comment on Waldron." Political Studies Review. https://doi.org/10.1177/1478929917704815 (December 18, 2017).

—. 2018a. "Beyond the Search for the Subject: An Anti-Essentialist Ontology for Liberal Democracy." European Journal of Political Theory OnlineFirst. https://doi.org/10.1177/1474885118763881 (March 29, 2018).

—. 2018b. “Can Deliberation Neutralise Power?” European Journal of Political Theory 17(3): 257-79.

Beitz, Charles R. 1989. Political Equality: An Essay in Democratic Theory. Princeton: Princeton University Press.

Bell, Daniel A. 2015. The China Model: Political Meritocracy and the Limits of Democracy. Princeton: Princeton University Press.

Bohman, James. 2006. "Deliberative Democracy and the Epistemic Benefits of Diversity." Episteme: A Journal of Social Epistemology 3(3): 175-191. 
Brennan, Jason. 2016. Against Democracy. Princeton: Princeton University Press.

Campbell, Angus, Philip E. Converse, Warren E. Miller, and Donald E. Stokes. 1960. The American Voter. Chicago: University of Chicago Press.

Caplan, Bryan. 2007. The Myth of the Rational Voter: Why Democracies Choose Bad Policies. Princeton: Princeton University Press.

Christiano, Thomas. 1996. The Rule of the Many: Fundamental Issues in Democratic Theory. Boulder, CO: Westview Press.

Coulthard, Glen Sean. 2014. Red Skin, White Masks: Rejecting the Colonial Politics of Recognition. Minneapolis: University of Minnesota Press.

Crouch, Colin. 2004. Post-Democracy. Malden, MA: Polity.

Davis, Angela Y. 2012. The Meaning of Freedom: And Other Difficult Dialogues. San Francisco, CA: City Lights Publishers.

Dietrich, Franz. 2008. “The Premises of Condorcet's Jury Theorem Are Not Simultaneously Justified." Episteme: A Journal of Social Epistemology 5(1): 56-73.

Disch, Lisa. 2011. "Toward a Mobilization Conception of Democratic Representation." American Political Science Review 105(1): 100-114.

Dresden, Jennifer Raymond, and Marc Morjé Howard. 2016. "Authoritarian Backsliding and the Concentration of Political Power." Democratization 23(7): 1122-43.

Dworkin, Ronald. 1996. Freedom's Law: The Moral Reading of the American Constitution. Cambridge: Harvard University Press.

El Amine, Loubna. 2016. "Beyond East and West: Reorienting Political Theory through the Prism of Modernity." Perspectives on Politics 14(1): 102-120.

Estlund, David. 1994. “Opinion Leaders, Independence, and Condorcet's Jury Theorem.” Theory and Decision 36(2): 131-62.

— 2008. Democratic Authority: A Philosophical Framework. Princeton: Princeton Univeristy Press.

Foa, Roberto Stefan, and Yascha Mounk. 2016. "The Democratic Disconnect.” Journal of Democracy 27(3): 5-17.

Fricker, Miranda. 2009. Epistemic Injustice: Power and the Ethics of Knowing. Oxford: Oxford University Press.

Fuerstein, Michael. 2008. "Epistemic Democracy and the Social Character of Justification." Episteme 5(1): 74-93. 
Fukuyama, Francis. 2014. Political Order and Political Decay: From the Industrial Revolution to the Globalization of Democracy. New York: Farrar, Straus and Giroux.

Galston, William. 2010. "Realism in Political Theory.” European Journal of Political Theory 9(4): 385-411.

Gaus, Gerald. 1997. "Does Democracy Reveal the Voice of the People? Four Takes on Rousseau." Australasian Journal of Philosophy 75(2): 141-162.

- 2011. "On Seeking the Truth (Whatever That Is) through Democracy: Estlund's Case for the Qualified Epistemic Claim.” Ethics 121(2): 270-300.

Gramsci, Antonio. 1971. Selections from the Prison Notebooks. eds. Quintin Hoare and Geoffrey Nowell Smith. New York: International Publishers.

Green, Jeffrey Edward. 2009. The Eyes of the People: Democracy in an Age of Spectatorship. Oxford: Oxford University Press.

- 2016. The Shadow of Unfairness: A Plebeian Theory of Liberal Democracy. New York, NY: Oxford University Press.

Griffin, Christopher G. 2003. "Democracy as a Non-Instrumentally Just Procedure.” Journal of Political Philosophy 11(1): 111-21.

Grofman, Bernard, and Scott L. Feld. 1988. "Rousseau's General Will: A Condorcetian Perspective." The American Political Science Review 82(2): 567-76.

Guerrero, Alexander A. 2014. "Against Elections: The Lottocratic Alternative.” Philosophy \& Public Affairs 42(2): 135-78.

Hayward, Clarissa Rile. 2013. How Americans Make Race: Stories, Institutions, Spaces. New York: Cambridge University Press.

Healy, Andrew, and Neil Malhotra. 2013. "Retrospective Voting Reconsidered." Annual Review of Political Science 16(1): 285-306.

Hong, Lu, and Scott E. Page. 2004. "Groups of Diverse Problem Solvers Can Outperform Groups of High-Ability Problem Solvers." Proceedings of the National Academy of Sciences of the United States of America 101(46): 16385-16389.

Hualing, Fu. 2015. "Wielding the Sword: President Xi’s New Anti-Corruption Campaign.” In Greed, Corruption and the Modern State: Essays in Political Economy, eds. Susan RoseAckerman and Paul Lagunes. Northampton, MA: Edward Elgar Publishing, 134-59.

Hui, Victoria Tin-bor. 2015. "The Protests and Beyond.” Journal of Democracy 26(2): 111-21.

- 2016. "Contribution to Symposium on Bell's China Model." Perspectives on Politics 14(1): 150-51. 
Humphrey, Mathew. 2007. Ecological Politics and Democratic Theory: The Challenge to the Deliberative Ideal. New York: Routledge.

Ingham, Sean. 2013. "Disagreement and Epistemic Arguments for Democracy.” Politics, Philosophy \& Economics 12(2): 136-55.

Issacharoff, Samuel, and Richard H. Pildes. 1998. "Politics As Markets: Partisan Lockups of the Democratic Process." Stanford Law Review 50(3): 643-717.

Jenco, Leigh. 2016. “Contribution to Symposium on Bell's China Model.” Perspectives on Politics 14(1): 152-53.

Kirshner, Alexander S. 2014. A Theory of Militant Democracy: The Ethics of Combatting Political Extremism. New Haven: Yale University Press.

Knight, Jack, and James Johnson. 2011. The Priority of Democracy: Political Consequences of Pragmatism. Princeton: Princeton University Press.

Kolodny, Niko. 2014. "Rule Over None I: What Justifies Democracy?” Philosophy \& Public Affairs 42(3): 195-229.

Landemore, Hélène. 2012. Democratic Reason: Politics, Collective Intelligence, and the Rule of the Many. Princeton: Princeton University Press.

Landemore, Hélène, and Jon Elster, eds. 2012. Collective Wisdom: Principles and Mechanisms. New York: Cambridge University Press.

Levinson, Daryl J., and Richard H. Pildes. 2006. "Separation of Parties, Not Powers." Harvard Law Review 119(8): 2311-86.

Levitsky, Steven, and Lucan A. Way. 2010. Competitive Authoritarianism: Hybrid Regimes after the Cold War. New York: Cambridge University Press.

Levitsky, Steven, and Daniel Ziblatt. 2018. How Democracies Die. New York: Crown.

Lindsey, Brink, and Steven Teles. 2017. The Captured Economy: How the Powerful Enrich Themselves, Slow Down Growth, and Increase Inequality. New York: Oxford University Press.

List, Christian, and Robert E. Goodin. 2001. "Epistemic Democracy: Generalizing the Condorcet Jury Theorem." Journal of Political Philosophy 9(3): 277-306.

Lodge, Milton, and Charles S. Taber. 2013. The Rationalizing Voter. Cambridge; New York: Cambridge University Press.

Longino, Helen E. 2013. Studying Human Behavior: How Scientists Investigate Aggression and Sexuality. Chicago: University of Chicago Press.

Malcolm X. 1964. The Ballot or the Bullet. Cleveland, OH. 
Mantena, Karuna. 2012. "Another Realism: The Politics of Gandhian Nonviolence.” American Political Science Review 106(02): 455-470.

Marks, Jonathan. 2009. Why I Am Not a Scientist: Anthropology and Modern Knowledge. Berkeley: University of California Press.

McNamee, Stephen J., and Robert K. Miller. 2013. The Meritocracy Myth. 3 edition. Lanham: Rowman \& Littlefield Publishers.

Medearis, John. 2015. Why Democracy Is Oppositional. Cambridge: Harvard University Press.

Medina, José. 2012. The Epistemology of Resistance: Gender and Racial Oppression, Epistemic Injustice, and Resistant Imaginations. Oxford: Oxford University Press.

Misak, Cheryl. 2008. "A Culture of Justification: The Pragmatist's Epistemic Argument for Democracy." Episteme: A Journal of Social Epistemology 5(1): 94-105.

Nathan, Andrew. 2016. "Contribution to Symposium on Bell's China Model." Perspectives on Politics 14(1): 154-55.

North, Douglass C., John Joseph Wallis, and Barry R. Weingast. 2009. Violence and Social Orders: A Conceptual Framework for Interpreting Recorded Human History. Cambridge: Cambridge University Press.

Ober, Josiah. 2008. Democracy and Knowledge: Innovation and Learning in Classical Athens. Princeton: Princeton University Press.

Ong, Lynette. 2016. “Contribution to Symposium on Bell's China Model." Perspectives on Politics 14(1): 156-57.

Oppenheimer, Danny, and Mike Edwards. 2012. Democracy Despite Itself: Why a System That Shouldn't Work at All Works So Well. Cambridge: MIT Press.

Pettit, Philip. 2013. On the People's Terms: A Republican Theory and Model of Democracy. Cambridge: Cambridge University Press.

Phulwani, Vijay. 2016. "The Poor Man's Machiavelli: Saul Alinsky and the Morality of Power." American Political Science Review 110(4): 863-75.

Przeworski, Adam. 1991. Democracy and the Market: Political and Economic Reforms in Eastern Europe and Latin America. Cambridge: Cambridge University Press.

— 1999. "Minimalist Conception of Democracy: A Defense." In Democracy's Value, eds. Ian Shapiro and Casiano Hacker-Cordon. Cambridge: Cambridge University Press.

—. 2005. "Democracy as an Equilibrium." Public Choice 123(3-4): 253-73.

- 2010. Democracy and the Limits of Self-Government. Cambridge: Cambridge University Press. 
Rahman, K. Sabeel. 2016. Democracy against Domination. Oxford: Oxford University Press.

Schwartzberg, Melissa. 2015. "Epistemic Democracy and Its Challenges." Annual Review of Political Science 18(1): 187-203.

Sen, Amartya. 1999. "Democracy as a Universal Value.” Journal of Democracy 10.

Shapiro, Ian. 2003. The State of Democratic Theory. Princeton: Princeton University Press.

- 2016. Politics against Domination. Cambridge: Belknap.

Somin, Ilya. 2013. Democracy and Political Ignorance: Why Smaller Government Is Smarter. First Edition. Stanford, CA: Stanford University Press.

- 2015. The Grasping Hand: "Kelo v. City of New London" and the Limits of Eminent Domain. Chicago ; London: University Of Chicago Press.

Stout, Jeffrey. 2012. Blessed Are the Organized: Grassroots Democracy in America. Princeton: Princeton University Press.

Sunstein, Cass R. 1987. “Lochner's Legacy.” Columbia Law Review 87(5): 873-919.

Svolik, Milan. n.d. "When Polarization Trumps Civic Virtue: Partisan Conflict and the Subversion of Democracy by Incumbents." New Haven, CT.

Tan, Kenneth Paul. 2008. "Meritocracy and Elitism in a Global City: Ideological Shifts in Singapore." International Political Science Review 29(1): 7-27.

Thompson, Abigail. 2014. "Does Diversity Trump Ability? An Example of the Misuse of Mathematics in the Social Sciences." Notices of the American Mathematical Society 61(9): 1024-30.

Tilly, Charles. 2007. Democracy. Cambridge: Cambridge University Press.

Van Hees, Martin. 2007. "The Limits of Epistemic Democracy." Social Choice and Welfare 28(4): 649-666.

Viehoff, Daniel. 2014. "Democratic Equality and Political Authority." Philosophy \& Public Affairs 42(4): 337-75.

Waldron, Jeremy. 1995. "The Wisdom of the Multitude: Some Reflections on Book 3, Chapter 11 of Aristotle's Politics." Political Theory 23(4): 563-84.

Wall, Steven. 2007. "Democracy and Equality.” The Philosophical Quarterly 57(228): 416-38.

Warren, Mark. 2011. "Voting with Your Feet: Exit-Based Empowerment in Democratic Theory." The American Political Science Review 105(4): 683-701. 
Williams, Bernard. 2005. In the Beginning Was the Deed: Realism and Moralism in Political Argument. ed. G. Hawthorn. Princeton: Princeton University Press.

Yuen, Samson. 2014. "Disciplining the Party: Xi Jinping's Anti-Corruption Campaign and Its Limits." China Perspectives 2014(2014/3): 41-47.

Zaller, John. 1992. The Nature and Origins of Mass Opinion. New York: Cambridge University Press. 